\section{$66.023: 536.24$}

[149]充てん層に和ける流体粒子間の熱移動〔〔E. B. Baumeister \& C.O. Bennett, A.I. Ch. E., J., 1958, Vol. 4, No. 1, p. 69〜74] 充てん雷は化学 工篦において触媒反沈装置, 乾燥装置, 吸着装置子ど として広く利用されており，流体粒子間の熱移動の研

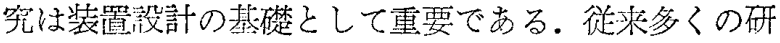
究が行われているが，測定值名研究者によってかなり 買なっている．熱移動速度の测定方法は種々あるが， 藷者らは直径 4 in の円筒に壳てんした $3 / 8,1 / 4,5 / 32$ in の銅鉄球を高周波加熱し，これに空気学通過さ计 て空気温度，材粗温息の变化より空気と球の間の熱伝 迲係数を求めている。测定值学 $j$ 因子の非で粒子径 基準の $R e$ 数に刘して耐対数紙上に点つづりし, 粒子 徍と容器径との比 $D / D_{p}$ によって偭斜の罢なる曲線 得ている.すなわち結果は $j_{n}=a R e^{b}$ で表わされ $a, b$ は $D / D_{p}$ の成数として

$$
a=0.918\left(1+0.0148 e^{0.565(18-D / D p)}\right)
$$

$b=-0.267-0.257 /\left(D / D_{p}-8.70\right)$ のごとく裴わさ れる. そして $a, b$ の平均值としては $a=1.09, b=$ - 0.32 を得ている. 從来よく使用されている Hougen らの值に比べて相当大きい值である．更に熱，物質ち よびモーメンタム移動のアナロジーについて䜊じて，

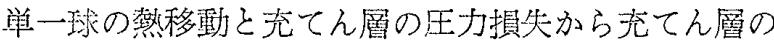
熱移動速磨の推定を試みている。 [平洞 正勝]

\subsection{1 .17}

〔150]タンデムコールドミルの自動厚み制御〔 $\mathrm{N}$. S. Walker, J.W. Cook, \& J.W. Wallace, Iron \& Steel Engr., 1958-7, Vol. 35, No. 7, p. 124 132, 图 12】この論交はウエスティングハウス方式によ るタンデムコールドミルの自動厚み制御を紹介してい 尚.

すなわち最終スタンド出口にある厚み計により目標 板㗨との相違を電気的に取り出し，これによって中央 スタンド（第 3 ）を基準に出入口侧スタンドの速㛿を 電压制街してスタンド間張力を調整，また同時に巻取 㖘力も調整して板愿を連続的に白動制街するものであ る。自動制卸の採用により笑際の板厚は手動のみによ る場合よりかなりの好結果を得られた事を図示してい る.

なおこの制衔方式にあわせてスクリューダウン制御 を行えば，より以上の成具を得られる事も解説してい る.これは第 1 スタンド出口の檿み計により第 1 ス夕 ンドスクリニーダウンを操作して，入口板厚の安定を 計るものであってこの制街回路ちよびブロックダイヤ グラムを示している。

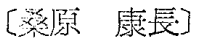

\subsection{2}

[151]サンプリング系に数ける signa! flow 線図 Q適用 [J.M. Salzer, 1957 IRE WESCON Convention Record, Part 4, 1957, p. 166 170, 図6]

連続量の系では，その signal How 線图艺知れば，

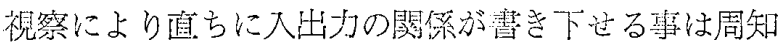

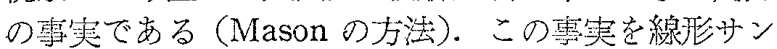

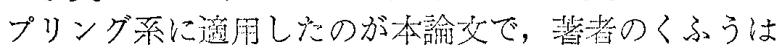
sampler のところを切断し，ここにサンプルされた 仮想の大力を老えて全体心 Mason の方法老適用市
るところにある。この力法によれば，出力量が直ちに 書き下ろせるばかりでなく, sampler を通過する信 号とそうでない信号とが分離される事，補熼回路をそ う大した場合，それが系のどの部分の，ぼの信号にに゙ う影響するかなどが出力を表わす式から難なく読み取 れる利点があり，シンセシスにも便利である。なお， 本交は sampler 1 個学含系の場合しか取扱ってい ないが，2個以上の場合にもこの方法生行列它用いる 事によってごく自然に拡張され，このところの解しい 事情を著者はいずれ発表すると約束して結んである。

[津田 阙志]

\section{$621-253: 539.43$}

※[152]ガスタービン車板のジャイロ荷重試験〔W. K. Wilson \& H.J. Harris, Instn. Mech. Engrs., Proc., 1957, Vol. 171, No. 27, p. 777 793, 図 16, 表2]研㠰の動機はコメット機がエルバ島附近で 丞落したさい 4 基のエンジンの中 3 基は夕ービン車板 と駆動軸をつなぐ中空軸に割れがあったが，タービン 車板はついていた。优の1基は倥軸のフランジで車 板が切れてなくなっていたのでこの原因を求めること であった。これは機体の急激疗姿樊変化のためにジャ イロ作用によって大きな曲げモーメントが㗢いたため と考えて，(i）コメットでおきたと考えられる条件范 特別に設計した試験台で実物エンジン（Ghost）で実 現してジャイ口荷重による破壊試験を行った。（ii）军 際の部品を用いて笑験空で瘦れ破壊試験を行った。 (iii）平滑および切父きのある試験片により疼れ試験 を行った。この結果（i）からはエンジンを9750 rpm で運転しているとき，2.6 rad/s で車板とノズルの間

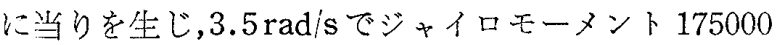
lb-inとなり，つなぎの架乹に割れを生じた。 (ii）からは $9750 \mathrm{rpm}$ で運転していると $0.63 \mathrm{rad} / \mathrm{s}$ (35000 lb-in の曲げモーメント) では每限回大丈夫, $13 \mathrm{rad} / \mathrm{s}(650000 \mathrm{lb}$-in の曲げモーメント相当) では 一僢間に割れを生ずることがわかった。この值は奏さ いに大形民間機に要求されるものよりもかなり大きい ので,この破壊は，丞落事故の結果としておこったも ので原因とはなりえないと結論している。（iii)からは 疲れ限度が $10^{3}$ 以下の（試験片に加えられる曲げモ 一メントが大きい）ときは切欠きのある力が鉵く, $10^{3}$ 以上の曲げモーメントが小さいときは平滑の試験圻の 方唯強いことが示された。このことは，エンジンの部 品分短時間的過荷重試賖にたえたとしても長時間には 大彗故の原因となることを示している。また，経浮お よび設計上の理由で少い繰迡し回数の応力にたえるよ

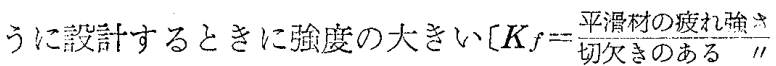
の大きいる材料を用いることが有利のように琶われるの も杂もしろいことであるとしている。

[命井策一毁]

\section{$536.242: 533.6 .011 .6$}

[153]マッハ数 0.87 から 5.05 にわたる乱流に新 污る熱伝達に関する測定実験の総合報告〔M.J. Brevoort \& B.D. Arabian, N.A.C.A. T.N. 4248 , 1958-5, pp. 43, 四 15, 表 1]乱流に打方䓡伝 達について前諭文（N.A.C.A. T.N. 3 303， 3374 , 